\title{
Properties of recombinant trehalose synthase from Deinococcus radiodurans expressed in Escherichia coli*
}

\author{
Paweł Filipkowski ${ }^{凶}$, Olga Pietrow, Anna Panek and Józef Synowiecki \\ Department of Food Chemistry, Technology and Biotechnology, Faculty of Chemistry, Gdansk University of Technology, Gdańsk, Poland
}

\begin{abstract}
A trehalose synthase gene from Deinococcus radiodurans (DSMZ 20539) containing 1659 bp reading frame encoding 552 amino acids was amplified using PCR. The gene was finally ligated into $\mathrm{pET} 30 \mathrm{Ek} / \mathrm{LIC}$ vector and expressed after isopropyl $\beta$-D-thiogalactopyranoside induction in Escherichia coli (DE3) Rosetta pLysS. The recombinant trehalose synthase (DraTres) containing a $\mathrm{His}_{6}$-tag at the C-terminus was purified by metal affinity chromatography and characterized. The expressed enzyme is a homodimer with molecular mass of $126.9 \mathrm{kDa}$ and exhibits the highest activity of $11.35 \mathrm{U} / \mathrm{mg}$ at $\mathrm{pH} 7.6$ and at $30^{\circ} \mathrm{C}$. DraTres activity was almost unchanged after $2 \mathrm{~h}$ preincubation at $45^{\circ} \mathrm{C}$ and $\mathrm{pH} 7.6$, and retained about $56 \%$ of maximal value after $8 \mathrm{~h}$ incubation at $50^{\circ} \mathrm{C}$. The DraTres was strongly inhibited by $\mathrm{Cu}^{2+}, \mathrm{Hg}^{2+}, \mathrm{Zn}^{2+}, \mathrm{Al}^{3+}$ and $10 \mathrm{mM}$ Tris. The $K_{\mathrm{m}}$ value of maltose conversion was $290.7 \mathrm{mM}$.
\end{abstract}

Key words: Deinococcus radiodurans, trehalose, trehalose synthase, gene expression, Escherichia coli

Received: 22 May, 2012; 23 August, 2012; accepted: 01 September, 2012; available on-line: 18 September, 2012

\section{INTRODUCTION}

D. radiodurans is a red pigmented, Gram-positive, non-pathogenic mesophile that propagates in a temperature range from $30^{\circ} \mathrm{C}$ to $37^{\circ} \mathrm{C}$. This bacteria is extremely resistant to ionizing radiation, ultraviolet light and desiccation (Lewis, 1971). D. radiodurans can be a potential source of an enzyme producing trehalose $(\alpha-\mathrm{D}-$ glucopyranosyl- $\alpha$-D-glucopyranoside). This stable, nonreducing disaccharide contains $\alpha, \alpha-1,1$-glucoside linkage between the $\alpha$-glucose moieties (Elbein et al., 2003). Trehalose can be used in the cosmetics, food, medical and biotechnological industries. The low sweetness of trehalose, good solubility in water, high water retention capabilities, stability, reduction of water activity, depression of freezing point and protein protection properties make it a valuable food ingredient (Teramoto et al., 2008). There are ideas for the stabilization of vaccines, enzymes, antibodies, hormones, pharmaceutical preparations and organs for transplantation (Richards et al., 2002; Higashiyama, 2002). One of the reasons for trehalose applications is participation in stabilization of proteins and/or biological membranes. Probably trehalose can form amorphous glass which entraps biological molecules without essential changes to their native structure during desiccation, freezing, heating or oxidation (Crove \& Crove, 2000; Roser, 1991; Benaroudi, 2001; Lenart et al., 1995). According to an alternate hypothesis trehalose can substitute water around biomolecules that provide hydrogen bonding network maintaining the structure of the protein. Trehalose is resistant to hydrolysis at low $\mathrm{pH}$ values and does not caramelize and does not participate in Maillard reactions. This compound has been accepted as a food additive and declared as GRAS (Generally Recognized As Safe) in the U.S. and at the EU respectively by FDA (Food and Drug Administration) and EFSA (European Food Safety Authority).

Enzymes involved in different pathways of trehalose biosynthesis were extensively studied (Schiraldi et al., 2002; Woo et al., 2010). There are known microorganisms which have only a single pathway, but some of them have two and even three trehalose biosynthesis pathways (Avonce, 2006). The most common biosynthesis pathway involves trehalose-6-phosphate synthase (TPS) which catalyses the transfer of glucose from uridine-diphosphate-glucose to glucose-6-phosphate. Afterwards, a trehalose-phosphate phosphatase (TPP) liberates phosphate forming trehalose. This pathway was described for Pyrococcus horikoshii and Saccharomycopsis fibuligera (Ryu et al., 2005, Liang et al., 2006). Another pathway, which involves two enzymes, was found in some hyperthermophilic archaeons, e.g.: Sulfolobus solfataricus, synthesising: maltooligosyltrehalose synthase (MTSase), and maltooligosyltrehalose trehalohydrolase (MTHase) to produce trehalose and oligosaccharide as intermediate (Kato, 1999). Recently, Pan et al. (2008), reported also a two step enzymatic production of trehalose from glycogen using MTSase and MTHase from Mycobacterium smegmatis. The third pathway, catalyzed by trehalose glycosyltransferring synthase (TreT), involves the conversion of nucleoside diphosphate glucose and glucose, instead of glucose-6-phosphate, into trehalose (Ryu et al., 2005; Empadinhas et al., 2006). On the other hand, production of trehalose in fungi such as Pleurotus ostreatus involves glucose-1-phosphate and glucose as substrates and trehalose phosphorylase (TreP) (Schwarz et al., 2007).

There is a possibility to use maltose- $\alpha$-D-glucosyl transferase, EC 5.4.99.16 (trehalose synthase, TreS) in industrial applications. This enzyme converted maltose into $\alpha, \alpha$-trehalose and released a small amount of glucose and $\alpha, \beta$-trehalose as by-products (Nishimoto et al., 1996a; Nishimoto et al., 1996b; Koh et al., 2003). According to

\footnotetext{
e-mail: pawel.filipkowski@pg.gda.pl

* Accesion number: JF957077

Abbreviations: GRAS, Generally Recognized As Safe; FDA, Food And Drug Administration; EFSA, European Food Safety Authority; DraTreS, trehalose synthase from $D$. radiodurans; DSMZ, Deutsche Sammlung von Mikroorganismen und Zellkulturen; $\mathrm{OD}_{600}$, optical density at $\lambda=600 \mathrm{~nm}$; PCR, polymerase chain reaction; DNA, deoxyribonucleic acid; EDTA, ethylenediaminetetraacetic acid; HPLC, high-performance liquid chromatography; SDS/PAGE, sodium dodecyl sulfate polyacrylamide gel electrophoresis; NCBI, National Center For Biotechnology Information
} 
many authors trehalose synthase is suitable for industrial manufacture of trehalose (Chen et al., 2006) because it allows one-step formation of trehalose and an inexpensive substrate, maltose derived from starch is employed. Wu et al. noticed in 2011 that this process is more promising than the bi-enzyme process currently used in industry. Maltose and glucose residues can be easily removed using a chromatographic process similar to purification of fructose manufactured from glucose. The fermentation route in yeast is too expensive because extraction and purification of trehalose require different reagents.

Up to now, trehalose synthases have been isolated from a variety of bacteria species, e.g., Pseudomonas putida, Thermus thermophilus, Meiothermus ruber and Arthrobacter aurescens (Ma et al., 2006; Zdziebło \& Synowiecki, 2006; Zhu et al., 2008; Xiuli et al., 2009). In the present work the gene encoding trehalose synthase from $D$. radiodurans (DraTreS) was cloned and expressed in E. coli. This is not the first report on $D$. radiodurans trehalose synthase. Wang et al. (2007) tried to use a part of dratres to determine the role of the C-terminus fragment of trehalose synthase.

\section{MATERIALS AND METHODS}

Bacterial strains, plasmids and culture conditions. D. radiodurans (DSMZ 20539, Braunschweig, Germany) was used as a source of the trehalose synthase gene. Bacterial cells were cultivated aerobically on a rotary shaker (Forma Orbital, Thermo Scientific, Marietta, OH, US) at $30^{\circ} \mathrm{C}(\mathrm{pH} 7.2)$ in a modified medium recommended by DSMZ as described previously (Kur et al., 2005). The E. coli TOP10F' (Invitrogen, Carlsbad, CA) and Rosetta (DE3) pLysS (Promega, Madison, WI) strains were used as a cloning host and expression host, respectively. The E. coli cells with plasmids were cultured aerobically at $37^{\circ} \mathrm{C}$ to $\mathrm{OD}_{600}$ of $0.3-0.5$ in $\mathrm{LB}$ medium supplemented with tetracycline $(1.25 \mu \mathrm{g} / \mathrm{ml})$ or chloramphenicol (34 $\mu \mathrm{g} / \mathrm{ml})$ and kanamycin $(20 \mu \mathrm{g} / \mathrm{ml})$, respectively. The cells were harvested by centrifugation at $3000 \times g$ for 10 min. The pJET (Fermentas UAB, Vilnius, Lithuania) and pET30Ek/LIC (Novagen, Darmstadt, Germany) plasmids were used for construction of an expression system. Restriction enzymes were purchased from Fermentas, Lithuania.

Amplification of trehalose synthase (DraTreS) gene and construction of expression vector. The deoxyribonucleic acid (DNA) from $D$. radiodurans isolated using a genomic DNA preparation kit (A\&A Biotechnology, Gdańsk, Poland) was used for amplification of DraTres gene in polymerase chain reaction (PCR) with two primers: 5' aa cat ATG ACC CAG GCA CAC CCG GA $3^{\prime}$ and 5' aa ctc gag ATT CAA CCG CAG CCA GTA ATA GTC 3' containing underlined recognition sites for restriction endonucleases NdeI and XhoI. The reaction was performed using $250 \mathrm{ng}$ of DNA, 10 pmoles of each primer, $12 \mu$ moles of dNTPs, $12.5 \mu \mathrm{l} 2$ $\times$ PCR buffer $\left(5 \mathrm{mM} \mathrm{MgCl}_{2}, 100 \mathrm{mM}\right.$ Tris, $\mathrm{pH}$ 9.0, 40 $\mathrm{mM}\left(\mathrm{NH}_{4}\right)_{2} \mathrm{SO}_{4}, 10 \mathrm{mM}$ DMSO) and $0.5 \mu \mathrm{l}$ Marathon DNA polymerase (Pwo \& Taq polymerase mixture). After 1 min of preliminary heating at $95^{\circ} \mathrm{C}$ in a thermal cycler (EpGradient S, Eppendorf, Hamburg, Germany) each of 30 cycles was conducted at $95^{\circ} \mathrm{C}$ for $1 \mathrm{~min}, 63.5^{\circ} \mathrm{C}$ for $1 \mathrm{~min}$ and $72^{\circ} \mathrm{C}$ for $2 \mathrm{~min}$, with a final step of 5 min at $72^{\circ} \mathrm{C}$. The DNA fragment encoding DraTres was obtained and cloned into pJET vector according to the producer's manual (CloneJet Kit). The competent E. coli TOP10F' cells suspended in $1 \mathrm{ml} 100 \mathrm{mM} \mathrm{CaCl}_{2}$ were transformed by the ligation mixture for $1 \mathrm{~h}$ at $8^{\circ} \mathrm{C}$ and after heat shock $\left(1.5 \mathrm{~min}\right.$ at $42^{\circ} \mathrm{C}$, then $1.5 \mathrm{~min}$ at $\left.4^{\circ} \mathrm{C}\right)$ incubated for $1 \mathrm{~h}$ at $37^{\circ} \mathrm{C}$ in $400 \mu \mathrm{l} \mathrm{SOC}$ medium (Invitrogen). The transformed E. coli cells were plated on LBagar tetracycline/ampicillin plates and incubated at $37^{\circ} \mathrm{C}$ for $16-18 \mathrm{~h}$. The obtained colonies were examined for the presence of the trehalose synthase gene of $D$. radiodurans by PCR amplification and restriction analysis. The presence of the DraTreS gene in transformed clones was confirmed by sequencing of the amplified DNA fragment. Then the appropriate sequence was digested with NdeI and XhoI restriction endonucleases and subcloned into a pET30Ek/LIC vector. The digestion product slightly smaller than $1700 \mathrm{bp}$ was isolated from agarose gel bands using the Gel-Out kit (A\&A Biotechnology). The obtained construct, designated as pET30Ek/LICDraTreS, was isolated and selected by electrophoresis on a $1 \%$ agarose gel and then used for transformation of $E$. coli Rosetta (DE3) pLysS cells.

Expression of the $\mathrm{His}_{6}$-tagged trehalose synthase. A single colony of transformed $E$. coli from LB-agar plates was inoculated in a $50 \mathrm{ml}$ liquid LB medium supplemented with kanamycin/chloramphenicol and cultivated at $37^{\circ} \mathrm{C}$. When $\mathrm{OD}_{600}$ reached the value of about $0.3-0.5$, the cell suspension was transferred to 21 of LB medium containing kanamycin/chloramphenicol. The cultures were grown up to $\mathrm{OD}_{600}$ of $0.3-0.5$ at conditions described above $\left(37^{\circ} \mathrm{C}\right)$, and then DraTreS expression in E. coli Rosetta (DE3) pLysS was induced at $25^{\circ} \mathrm{C}$ with isopropyl $\beta$-D-thiogalactopyranoside (IPTG) at a final concentration of $1 \mathrm{mM}$. The cells were harvested 18 $\mathrm{h}$ after induction by centrifugation and the pellet washed with distilled water was centrifuged and stored at $-20^{\circ} \mathrm{C}$ until use.

Isolation and purification of recombinant trehalose synthase. Transformed E. coli cells, harvested by centrifugation $\left(6000 \times \mathrm{g}, 15 \mathrm{~min}, 15^{\circ} \mathrm{C}\right)$ from 21 of induced culture, were homogenized and sonicated at 20 $\mathrm{kHz}$ (three times for $30 \mathrm{~s}$ with $30 \mathrm{~s}$ intervals) in $80 \mathrm{ml} 50$ $\mathrm{mM}$ phosphate buffer ( $\mathrm{pH}$ 7.6) containing 1 M EDTA, $100 \mathrm{mM} \mathrm{CaCl}_{2}, 0.1 \mathrm{mg}$ lysozyme and $1 \mathrm{mg}$ RNase, using Brenson Ultrasonic Sonifier II W250D (Geneve, Switzerland). The resulting suspension was centrifuged $\left(8^{\circ} \mathrm{C}\right)$ at $9000 \times \mathrm{g}$ for $40 \mathrm{~min}$. Total cell lysate was incubated at $56^{\circ} \mathrm{C}$ for $10 \mathrm{~min}$ and precipitated host proteins were removed by centrifugation at $12000 \times \mathrm{g}$ for $40 \mathrm{~min}$. The obtained supernatant was then applied to $\mathrm{Co}^{2+}$-IDAagarose column (His $\times$ Bind ${ }^{\circledR}$ Resin, Novagen) equilibrated with $50 \mathrm{ml}$ of $0.1 \mathrm{M}$ phosphate buffer ( $\mathrm{pH}$ 7.6) containing $\mathrm{NaCl}$ and imidazole at concentrations $0.5 \mathrm{M}$ and 5 $\mathrm{mM}$, respectively (buffer A). After loading, the column was washed three times with $50 \mathrm{ml}$ of the same buffer. The recombinant DraTres was then washed twice with $20 \mathrm{ml}$ of buffers A, A', B, C, D containing imidazole concentrations 5, 25,50,80, $100 \mathrm{mM}$, respectively. The protein of interest was eluted with two portions of $20 \mathrm{ml}$ elution buffer $\mathrm{E}$ containing imidazole at concentration of $0.5 \mathrm{M}$. The eluted fraction was desalted and concentrated on a Centrifugal Filter Device (Amicon ${ }^{\circledR}$ Ultra-15 30000 MWCO Carrightwohill, Cork, Ireland) and used as a final preparation of the enzyme.

Enzyme assay. The activity of DraTres was determined by measuring the trehalose produced from maltose. The assays were initiated by the addition of $0.1 \mathrm{ml}$ of DraTreS solution to $1.0 \mathrm{ml}$ of $0.3 \mathrm{M}$ maltose solution in a $0.1 \mathrm{M}$ phosphate citrate buffer $(\mathrm{pH}$ 7.6). The reaction at $30^{\circ} \mathrm{C}$ was terminated after sample heating at $100^{\circ} \mathrm{C}$ for $10 \mathrm{~min}$. The samples purified by centrifugation $(10000 \times g, 10 \mathrm{~min})$ and filtration on a 


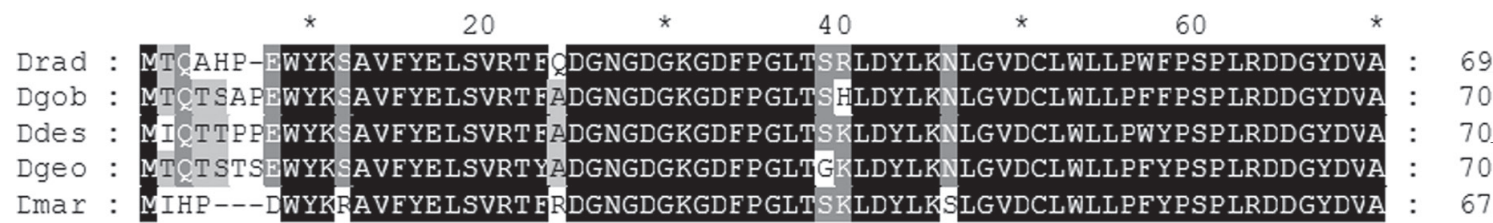

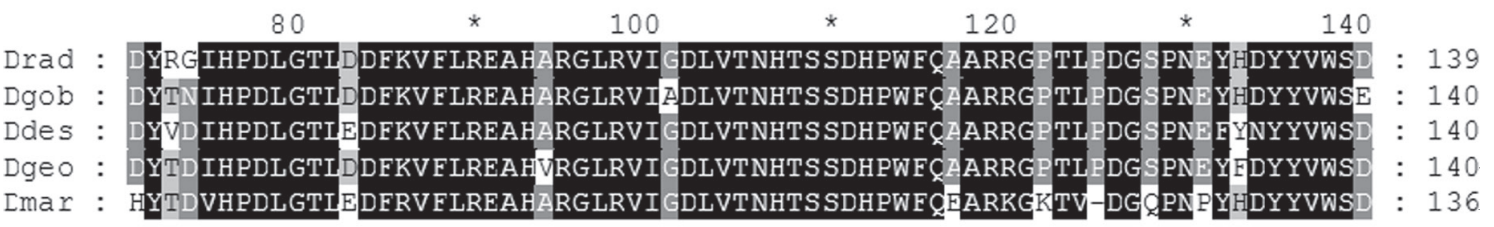

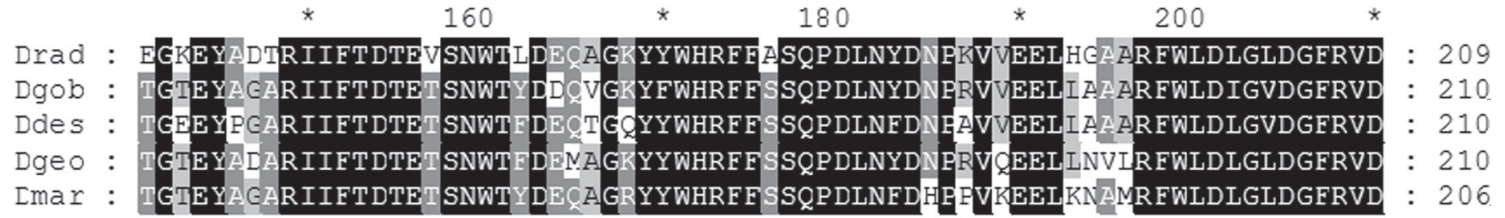

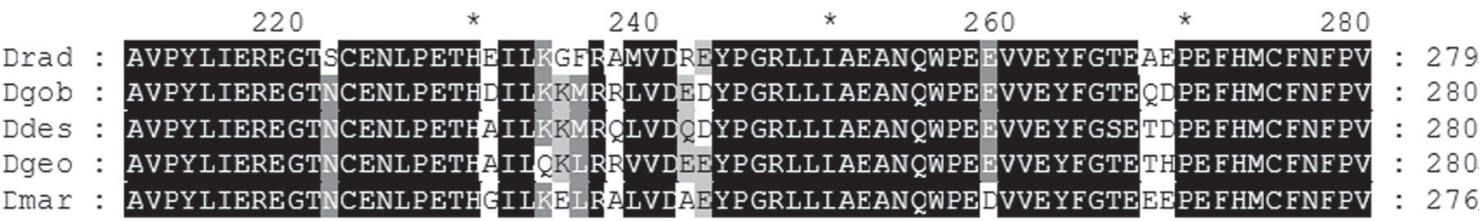

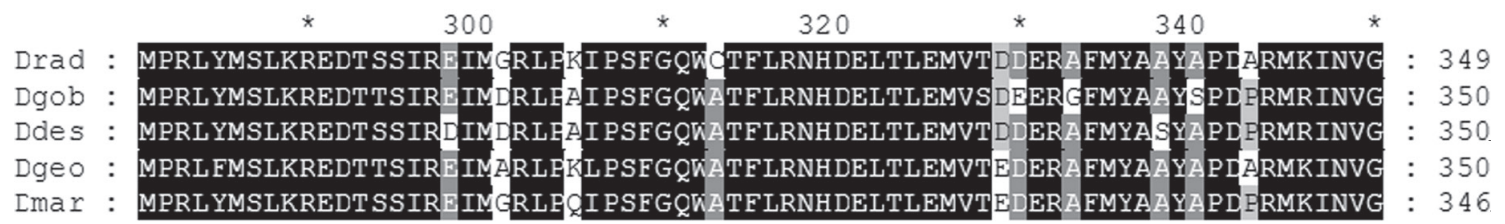

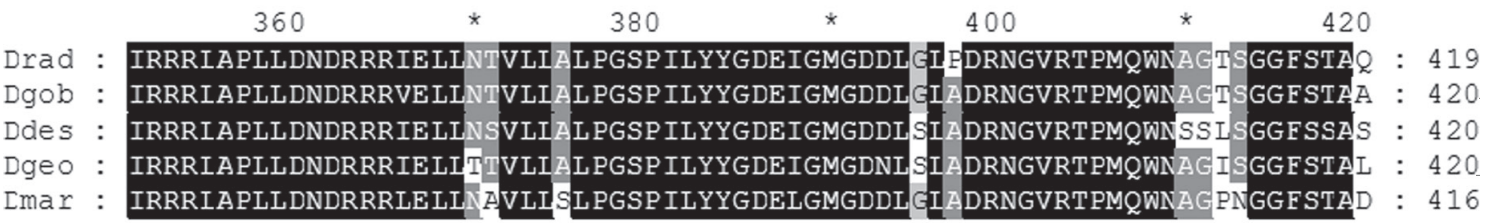
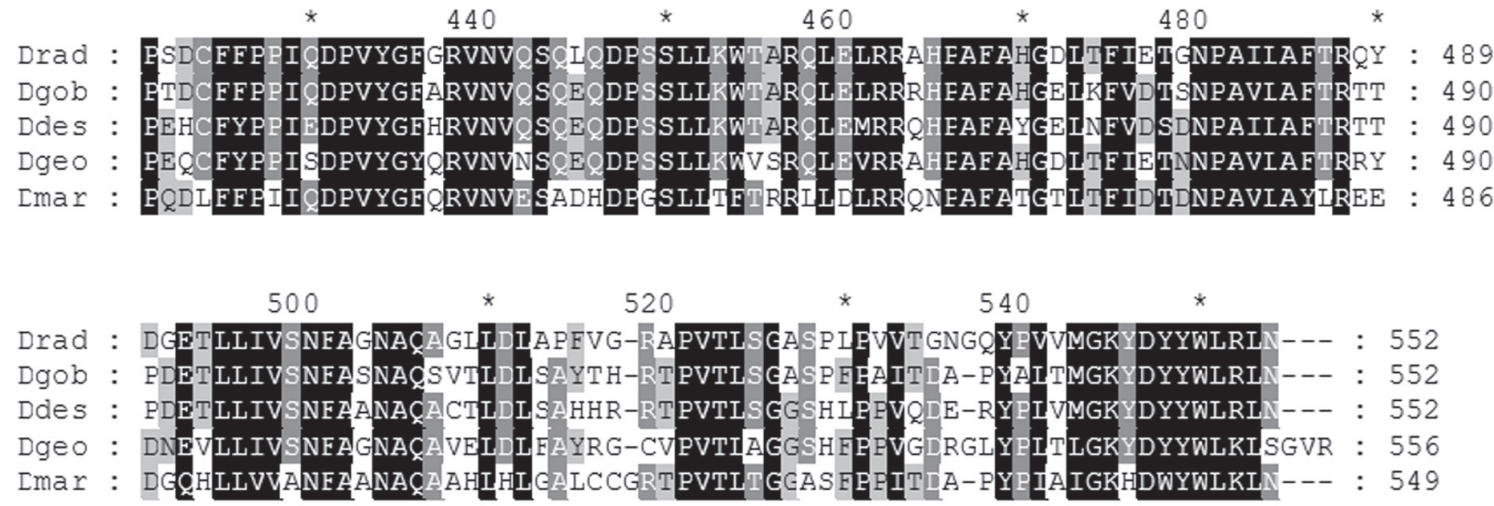

Figure 1. Multiple amino acid sequence alignment of TreS proteins.

Description of similarity: white fonts on black boxes $100 \%$ identity; white fonts on grey boxes similarity $<80 \%$; black fonts on grey boxes similarity < 60\%. Dra, D. radiodurans; Dgob, D. gobiensis; Ddes, D. deserti; Dgeo, D. geothermalis; Dmar, D. maricopensis. 
0.2 um Chromafil ${ }^{\circledR}$ PEF 20/25 filter (Machery-Nagel GmbH, Duren, Germany) were passed through a APS2 HYPERSIL column (Thermo Electron Corporation, Dreiech, Germany) using acetonitrile/methanol/water $(78: 11: 11, \mathrm{v} / \mathrm{v} / \mathrm{v})$ as mobile phase at a flow rate of 1.6 $\mathrm{ml} / \mathrm{min}$. The column temperature was $30^{\circ} \mathrm{C}$ (modified method from Drożdżyńska et al., 2009). The amounts of the products formed during conversion of maltose were calculated from the area of the peaks obtained after sample separation by HPLC using a refractive index detector (La Chrom-7490, Merck, Hitachi, Tokyo, Japan). Trehalose, maltose and glucose were used as standards at concentrations of $10 \mathrm{mg} / \mathrm{ml}$.

DraTreS activity was expressed as the amount of enzyme that produces $1 \mu \mathrm{mol}$ of trehalose per minute under described conditions. The relative enzyme activity $(\%)$ was defined as the percentage of enzyme activity in the control.

The temperature dependence of enzyme activity was assayed in the range $0-55^{\circ} \mathrm{C}$. The $\mathrm{pH}$ stability of $\mathrm{Dra}$ TreS was determined by measuring the residual activities after $2 \mathrm{~h}$ incubation $\left(30^{\circ} \mathrm{C}\right)$ in $50 \mathrm{mM}$ Britton-Robinson buffers at various $\mathrm{pH}$ values. The thermostability of trehalose synthase was investigated by incubation of enzyme solution in $0.1 \mathrm{M}$ phosphate citrate buffer $(\mathrm{pH}$ 7.6) at $10-60^{\circ} \mathrm{C}$ for 2 hours. Protein concentrations were determined by the Lowry method (Lowry et al., 1952). The effects of metal ions and chemicals were determined according to standard procedure with $0.3 \mathrm{M}$ maltose solution in water containing a final concentration of cations or chemicals given in Table 2.

Protein sequence analysis. The amino acid sequence of DraTreS was analyzed using standard protein-protein BLAST and RPS-BLAST. Multiple sequence alignment was generated by using the program ClustalX. The results were prepared using the editor program Gendoc (copyright Karl Nicholas).

Molecular mass determination of recombinant DraTreS. The purified DraTreS was applied on a Superdex 200 HR 10/30 column (Amersham Bioscence AB, Uppsala, Sweden) equilibrated with $150 \mathrm{mM} \mathrm{NaCl}$ and $10 \mathrm{mM}$ EDTA in a phosphate buffer $(\mathrm{pH} 7.5)$ and then was eluted with the same buffer. Absorbance at $280 \mathrm{~nm}$ was measured to monitor the elution profile. The elution patterns of recombinant DraTreS proteins were then compared with those of standard proteins: carbonic an-

A

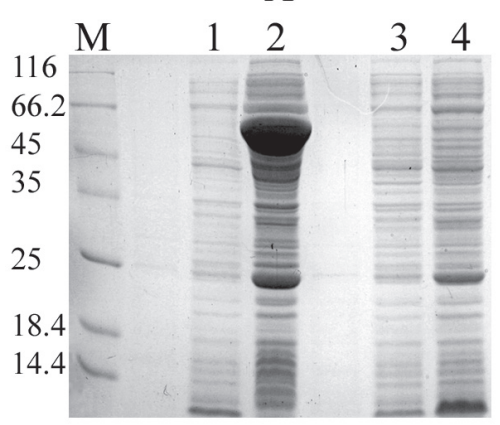

Figure 2. SDS/PAGE of protein in the fraction during purification steps of recombinant DraTres.

Lanes: M - protein marker (Fermentas SM0431, size of proteins at $\mathrm{kDa}$ ), lane $\mathrm{A} 1$ - recombinant $E$. coli strain with vector before induction, lane A2 - cell extract after $18 \mathrm{~h}$ of protein expression induced by IPTG, lane A3 - control $E$. coli strain with vector $\mathrm{pET}$ only before induction, lane A4 - control $E$. coli strain with vector pET only after $18 \mathrm{~h}$ of IPTG induction, lane B5 - heat treatment at $56^{\circ} \mathrm{C}$ for $10 \mathrm{~min}$, lane $\mathrm{B} 6-$ purified DraTreS after $\mathrm{Co}^{2+}-$ affinity chromatography. hydrase $(29 \mathrm{kDa})$, ovoalbumin $(43 \mathrm{kDa})$, monomer of bovine serum albumin $(66 \mathrm{kDa})$, alcohol dehydrogenase $(150 \mathrm{kDa}), \beta$-amylase $(200 \mathrm{kDa})$, apoferritin $(443 \mathrm{kDa})$ and thyroglobulin $(669 \mathrm{kDa})$.

The molecular mass of the enzyme subunit was determined by sodium dodecylsulphate polyacrylamide gel electrophoresis (SDS/PAGE) using $12 \%$ (w/v) polyacrylamide gel in a Tris-glycine buffer $(\mathrm{pH} 8.3)$ (Laemmli 1970). The samples $(20 \mu \mathrm{l})$ denatured by $\beta$-mercaptoethanol as a reducing agent and SDS were layered on the gel and separated using a voltage gradient of $15 \mathrm{~V} / \mathrm{cm}$. Protein bands were located by staining with Coomassie Brillant Blue R250. The molecular mass was determined using a molecular mass marker kit (Fermentas). Purity and molecular mass were determined from SDS/PAGE gels with Quantity One Software (BioRad, CA, USA).

\section{RESULTS AND DISCUSSION}

\section{Cloning of DraTres}

This study concerns the previously cloned recombinant trehalose synthase from $D$. radiodurans. The cloning experiments were performed using the sequence annotated as a putative trehalose synthase in GenBank (locus DR-2036, accession no. AE000513 GI: 6459827). The CAZy database shows that trehalose synthase share common structural features with the members of the glucoside hydrolase family (GH13) (Cantarel et al., 2009).

Our experiments confirm that the wild-type region of the $D$. radiodurans gene amplified by PCR had a sequence consisted of 1659 nucleotides encoding 552 amino acid residues (Fig. 1) and that with oligohistidine tags has two additional amino acids: Leu and Glu and consisted of 1683 nucleotides and 560 amino acid residues. These two extra residues are connected with construction of the gene encoding DraTres in vector pET30Ek/LIC. Theoretical values of molecular mass $\left(M_{\mathrm{r}}\right)$ and isoelectric point of the native enzyme were calculated to be $62.71 \mathrm{kDa}$ and $\mathrm{pI}$ 4.94, respectively (data for recombinant protein containing the $\mathrm{His}_{6}$ tag at the $\mathrm{C}$-terminus preceded by two residues were $64.69 \mathrm{kDa}$ and $\mathrm{pI} 5.13$ ). The $\mathrm{M}_{\mathrm{r}}$ value deduced from the amino acid sequence of the enzyme was confirmed by SDS/PAGE (Fig. 2). To determine the oligomeric state of this protein, it was analyzed by gel filtration chromatography, which showed that native DraTreS has the molecular mass of $126.9 \mathrm{kDa}$ (Fig. 3). Data obtained from this experiment suggest that DraTreS exists as homodimer.

Efficient overexpression of the gene was observed in E. coli Rosetta (DE3) pLysS (which can recognize rare codons) at $25^{\circ} \mathrm{C}$. After analysis of Rare Codon Usage with software from www.kazusa.org.jp we can say that in the DraTreS gene there are 22 rare codons recognized by the E. coli Rosetta strain: $1 \times$ Gly, $1 \times$ Arg, $20 \times$ Pro. Problems with efficient overexpression of genes containing rare codons were also noticed for example by Yue et al., (2009).

\section{Characterization of DraTreS}

The comparison of molecular mass $\left(M_{\mathrm{r}}\right)$ and some other properties of DraTreS and that for trehalose synthases from other bacteria is shown in Table 1. Similar $M_{\mathrm{r}}$ values were reported for subunits of trehalose synthases from Pseudomonas sp. F1 (Ohguchi M et al., 1997), D. radiodurans (Wang et al., 2007), and Pimelobacter sp. R48 (Nishimoto et al., 1996a). In comparison with enzymes from these sources, a higher $M_{\mathrm{r}}$ value was detect- 
Table 1. Properties of different trehalose synthases.

\begin{tabular}{|c|c|c|c|c|c|c|}
\hline Trehalose synthase from: & $\begin{array}{l}\text { Molecular } \\
\text { mass (kDa) }\end{array}$ & $\begin{array}{l}\text { Optimal tempe- } \\
\text { rature }\left({ }^{\circ} \mathrm{C}\right)\end{array}$ & Optima pH & Thermostability & pH stability & References \\
\hline Deinococcus radiodurans & $64^{*(\mathrm{His} 6)}$ & 30 & 7.6 & $\begin{array}{l}\text { Below } 40^{\circ} \mathrm{C} \\
(2 \mathrm{~h})\end{array}$ & $\begin{array}{l}5.5-9.5 \\
(2 \mathrm{~h})\end{array}$ & This study \\
\hline Deinococcus radiodurans & 61 & 15 & 6.5 & $\begin{array}{l}\text { Below } 40^{\circ} \mathrm{C} \\
(0.5 \mathrm{~h}\end{array}$ & $\begin{array}{l}5.5-8.0 \\
(2 \mathrm{~h})\end{array}$ & Wang et al., 2007 \\
\hline Pimelobacter sp. R48 & 62 & 20 & 7.5 & $\begin{array}{l}\text { Below } 30^{\circ} \mathrm{C} \\
(2 \mathrm{~h})\end{array}$ & $\begin{array}{l}6.0-9.0 \\
(1 \mathrm{~h})\end{array}$ & Nishimoto et al., 1996 \\
\hline Pseudomonas sp. F1 & 67 & 45 & 7.0 & $\begin{array}{l}\text { Below } 55^{\circ} \mathrm{C} \\
(2 \mathrm{~h})\end{array}$ & $\begin{array}{l}7.0-9.0 \\
(1 \mathrm{~h})\end{array}$ & Ohguchi et al., 1997 \\
\hline Thermus aquaticus & 105 & 65 & 6.5 & $\begin{array}{l}\text { Below } 80^{\circ} \mathrm{C} \\
(2 \mathrm{~h})\end{array}$ & $\begin{array}{l}5.5-9.5 \\
(1 \mathrm{~h})\end{array}$ & Nishimoto et al., 1996 \\
\hline Thermus thermophilus & 106 & 65 & 6.5 & $\begin{array}{l}\text { Below } 80^{\circ} \mathrm{C} \\
(2 \mathrm{~h})\end{array}$ & $\begin{array}{l}6.0-9.0 \\
(2 \mathrm{~h})\end{array}$ & Wang et al., 2007 \\
\hline
\end{tabular}

ed for T. aquaticus and T. thermophilus (Nishimoto et al., 1996b; Zdziebło \& Synowiecki 2006).

The analysis of the primary structures revealed the presence of several regions common to previously reported proteins of the Deinococcus/Thermus phylum (Wang et al. 2007). The comparison of DraTreS sequences and those for trehalose synthases from D. gopiensis, $D$. desertii, $D$. geothermalis, $D$. maricopensis shows that even within the Deinococcus phylum there are significant differences. The sequence of DraTreS shares 83 to $84 \%$ identity and 89 to $90 \%$ similarity with D. gopiensis, D. desertii, D. geothermalis and 78\% identity and 89\% similarity to $D$. maricopensis. More similar fragments are located on the N-terminus of the protein molecules (Fig. 1). Further comparison using Blast tools (NCBI) indicated that Corallococcus coralloides, Thermobaculum terrenum, Streptomyces bygroscopicus subsp. Jinggangensis TreS sequences have 56\%, $55 \%, 46 \%$ identity and $71 \%, 70 \%, 69 \%$ similarity, respectively to DraTreS (data not shown on Fig 1.).

\section{Activity and kinetics of maltose conversion}

Single step purification of the enzyme by metal affinity chromatography allowed $17 \%$ of protein recovery. The obtained results showed that the enzyme could convert maltose to trehalose accompanied by a low level of glucose as a by-product. The small amount of glucose usually released in most of the reactions catalyzed

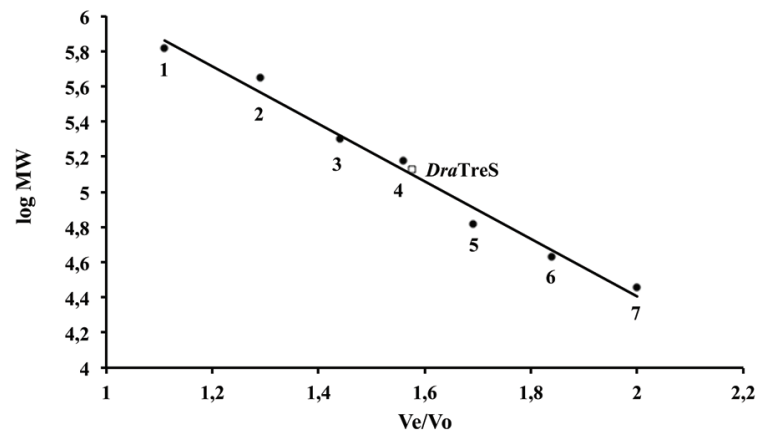

Figure 3. DraTreS molecular mass determination by gel filtration chromatography on Superdex 200 HR 10/30.

The molecular mass standards $(0)$ are represented by a number from 1 to 7 , respectively: thyroglobulin $(669 \mathrm{kDa})$, apoferritin (443 $\mathrm{kDa}), \beta$-amylase (200 kDa), alcohol dehydrogenase (150 kDa), bovine serum albumin $(66 \mathrm{kDa})$, ovoalbumin $(43 \mathrm{kDa})$ and carbonic anhydrase $(29 \mathrm{kDa})$. Retention rate $\mathrm{V}_{\mathrm{e}} / \mathrm{V}_{0}$, where: $\mathrm{V}_{\mathrm{e}}$ elution volume of each protein, $V_{0}$ void volume of the column determined with blue dextran. by trehalose synthases is generated under entry of water molecules into the catalytic site prior to isomerization of the glycosidic linkage (Koh at al., 2003). This weak hydrolytic action of trehalose synthases depends on the enzyme origin and increases with temperature of reaction (Wei et al. 2004).

The temperature optimum for maltose conversion was found to be $30^{\circ} \mathrm{C}$ (Fig. 4) and this value was higher than that for the trehalose synthase of $D$. radiodurans reported previously by Wang et al., (2007).

Furthermore in the case of other trehalose synthases produced by mesophilic bacteria, the optimal temperature is higher by about few degrees than the growth temperature of the bacteria and never lower. Optimal temperature for trehalose synthase from $P$. putida, Corynebacterium glutamicum and Enterobacter hormaechei is $35^{\circ} \mathrm{C}, 35^{\circ} \mathrm{C}$ and $37^{\circ} \mathrm{C}$, respectively (Ma et al., 2006; TaeKyun et al., 2010; Yue et al., 2009). However, growth of $D$. radiodurans was not observed at temperature $10^{\circ} \mathrm{C}$ or at $45^{\circ} \mathrm{C}$ (Lewis 1971).

The thermostability of DraTreS reported in this article was not as high as that of the enzyme from the genus Thermus (Table 1). The half-life of DraTreS (examined in this work) activity at $40^{\circ} \mathrm{C}(\mathrm{pH} 7.6)$ was $28.5 \mathrm{~h}$, while previously described trehalose synthase from $D$. radiodurans showed similar activity after incubating at the same temperature for $30 \mathrm{~min}$ (Wang et al., 2007). When the thermostability of DraTreS was examined at $50^{\circ} \mathrm{C}$ and $55^{\circ} \mathrm{C}$ the enzyme retained $50 \%$ of its maximal activity after $9.5 \mathrm{~h}$ and $0.5 \mathrm{~h}$ of incubation, respectively.

The optimal pH for maltose conversion was 7.6 (in 0.1 $\mathrm{M}$ phosphate citrate buffer) as shown in Fig. 5. This $\mathrm{pH}$ value is similar to that reported for trehalose synthases

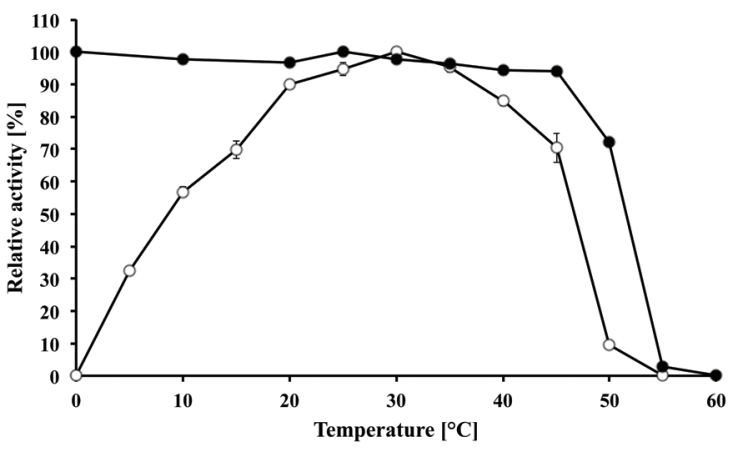

Figure 4. Optimal temperature and thermostability of DraTreS. Activity $(O)$ and stability $(\bullet)$ at $\mathrm{pH}$ 7.6. The results are mean values of three replicates. 


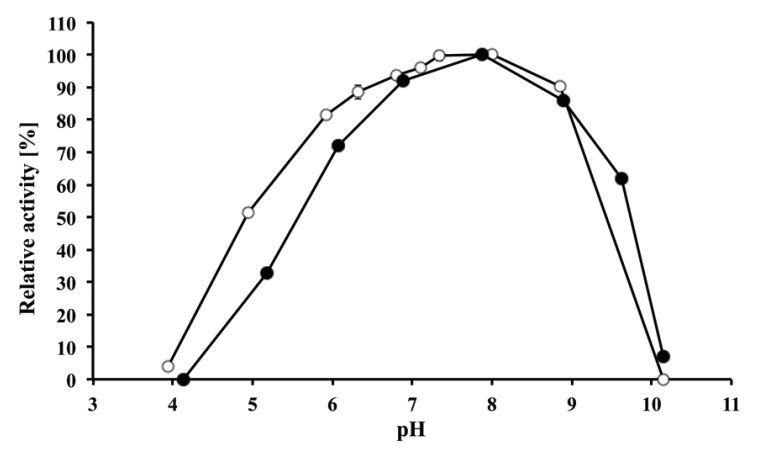

Figure 5. Optimal pH and pH-stability of DraTreS.

Activity $(O)$ and stability (O). The $\mathrm{pH}$ stability was determined by measuring residual activity after $2 \mathrm{~h}$ incubation at $30^{\circ} \mathrm{C}$ in the same buffer as those used for the optimal pH determination.

from Pimelobacter sp. R48 (Nishimoto et al., 1996a) and T. aquaticus (Nishimoto et al., 1996b). The retention of about $50 \%$ of maximal activity of DraTreS was observed at a wide $\mathrm{pH}$ range of 5.5 to 9.5 (Fig. 5). This suggests that DraTreS might be useful for industrial trehalose production. Even if we used 10\% maltose solution as a substrate no more than $7.5 \%$ of it was converted to glucose as a by-product after $32 \mathrm{~h}$ of the reaction (Fig. 6).

The obtained enzyme had the specific activity of 11.35 $\mathrm{U} / \mathrm{mg}$. The $K_{\mathrm{m}}$ values calculated using Lineweaver-Burk plot (Lineweaver \& Burk 1934) for recombinant DraTreS were found to be $290.7 \mathrm{mM}$ for maltose and $486.14 \mathrm{mM}$ for trehalose. With regard to this result the recombinant DraTres had a lower affinity to maltose than enzymes from T. aquaticus ( $\left.K_{\mathrm{m}} 34.5 \mathrm{mM}\right)$ (Nishimoto et al., 1997) and E. hormaechei ( $\left.K_{\mathrm{m}} 25 \mathrm{mM}\right)$ (Yue at al., 2009). Furthermore, the $K_{\mathrm{m}}$ value of trehalose-synthesizing enzyme from Pseudomonas sp. F1 was $1.1 \mathrm{mM}$ (Ohguchi et al., 1997). The turnover number $\left(k_{\text {cat }}\right)$ values of recombinant DraTreS for maltose and trehalose were $23.6 \mathrm{~s}^{-1}$ and $17.5 \mathrm{~s}^{-1}$, respectively. To compare trehalose synthase from Meiothermus ruber is characterized by $k_{\text {cat }}$ equal $147.0 \mathrm{~s}^{-1}$ for malt-

Table 2. Effect of some cations and chemicals on activity of trehalose synthase from $D$. radiodurans expressed in $E$. coli.

\begin{tabular}{lccc}
\hline \multirow{2}{*}{ Cation/Chemical } & \multicolumn{3}{c}{ Relative activity (\%) at reagent } \\
concentration of
\end{tabular}

Results are mean values of three determinations \pm standard deviation. nd, not determined

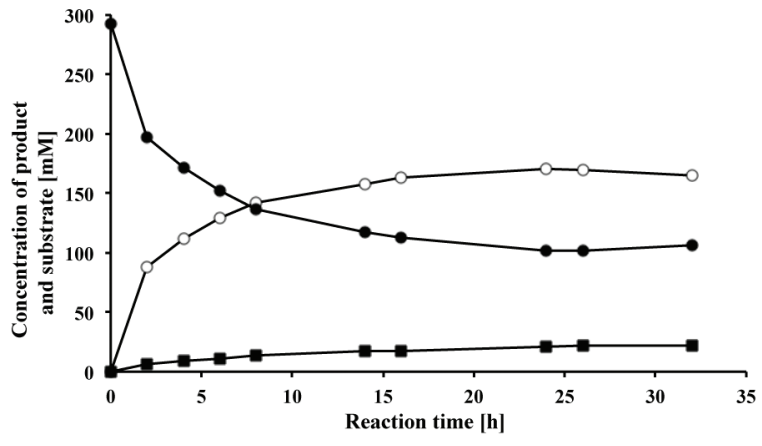

Figure 6. Effect of reaction time at $30^{\circ} \mathrm{C}$ on the trehalose $(\bigcirc)$ and glucose $(\square)$ formation in $0.3 \mathrm{M}$ solution of maltose $(0)$ in phosphate citrate buffer ( $\mathrm{pH} 7.6)$.

ose conversion and $k_{\text {cat }} 68.9 \mathrm{~s}^{-1}$ for trehalose conversion (Zhu et al., 2010). Moreover DraTres had over twofold higher enzyme efficiency $\left(k_{\text {cat }} / K_{\mathrm{m}}\right)$ toward maltose $(0.081$ $\left.\mathrm{mM}^{-1} \times \mathrm{s}^{-1}\right)$ than trehalose $\left(0.036 \mathrm{mM}^{-1} \times \mathrm{s}^{-1}\right)$ indicating maltose as the preferred substrate. A similar situation was noticed for trehalose synthase from $M$. ruber and Picrophilus torridus (Zhu et al., 2010, Chen et al., 2006).

The effect of reaction time on the yield of trehalose by DraTreS was determined at $30^{\circ} \mathrm{C}$ using a $0.3 \mathrm{M}$ solution of maltose in $0.1 \mathrm{M}$ phosphate citrate buffer ( $\mathrm{pH}$ 7.6). The reaction was almost terminated after $24 \mathrm{~h}$ and $65.27 \%$ of the substrate was converted into $58.16 \%$ of trehalose and $7.11 \%$ of glucose (Fig. 6). It indicates that the equilibrium between conversion of maltose into trehalose and reverse reaction was achieved. Maximum conversion of maltose into trehalose depends on enzyme sources. A similar value of conversion was for example reported by Chen et al. (2006) for the enzyme from $P$. torridus.

\section{Effect of some cations and chemicals on DraTres activity}

Data reported in Table 2 indicated that the enzyme was highly sensitive to $\mathrm{Hg}^{2+}, \mathrm{Al}^{3+}, \mathrm{Zn}^{2+}$ and $\mathrm{Cu}^{2+}$ while $\mathrm{Ca}^{2+}$ and $\mathrm{Mg}^{2+}$ did not significantly affect the catalytic activity of the enzyme at concentrations of $1 \mathrm{mM}$. However, at a concentration of $5 \mathrm{mM}$ almost all examined cations decreased DraTreS activity. EDTA causes DraTreS inactivation when the concentration of this chelator was increased (Table 2). It is known that cations like $\mathrm{Ca}^{2+}$ or $\mathrm{Zn}^{2+}$ are required for enzyme activity analogical to other members of GH13 hydrolases, which have binding sites with different affinity to metal ions. $\mathrm{Ca}^{2+}$ stabilizes the linkage of the $(\alpha / \beta)_{8}$-barrel. Removal of this ion by EDTA causes enzyme inactivation. Attachment of bivalent cations to other metal binding sites is responsible for unfolding of the protein structure and enzyme inactivation at increased concentration of the cations (Linden et al., 2003; Janecek 1997).

The results presented in Table 2 indicating strong inhibition of DraTreS by $10 \mathrm{mM}$ Tris are rather surprising but that was also reported for trehalose synthases originating from Pimelobacter sp.48, Arthrobacter aurescens, T. thermophilus and M. smegmatis (Nishimoto et al., 1996a; Xiuli et al., 200; Wang et al., 2007; Pan et al., 2004, Wei et al., 2000). It seems that this is connected with the ionic strength and the presence of $\mathrm{Cl}^{-}$.

No effect on activity in the case of dithiothreitol, which acts as a suppressor of thiol group oxidation, suggests that reduction of disulfide bridges does not influence the active site and catalytic properties of DraTreS. 


\section{CONCLUSIONS}

It is the purpose of the present study to obtain further evidence for the trehalose synthases. This work indicates the potential for the production of $D$. radiodurans strain trehalose synthase by an E. coli expression system. In our study we characterized the properties of the obtained recombinant enzyme and compared them with that for other trehalose synthases from other bacterial species. DraTres reported here is fully active at moderate temperature $\left(30^{\circ} \mathrm{C}\right)$ and their acid resistance is similar to that reported to many other trehalose synthases This report on the trehalose synthase from $D$. radiodurans allowed broadening our knowledge about the biodiversity of microbial sources of this enzyme.

\section{Acknowledgments}

We thank the scientists from the Department of Microbiology, Technical University of Gdansk for determination of the native molecular weight of DraTreS.

This research work was supported by the system project "InnoDoktorant - Scholarships for $\mathrm{PhD}$ students, IVth edition". Project is co-financed by the European Union in the frame of the European Social Fund. Project is co-financed by Pomeranian Special Economic Zone and Gdansk Science and Technology Park.

\section{REFERENCES}

Avonce N, Mendoza-Vargas A, Morett E, Iturriaga G (2006) Insights on the evolution of trehalose biosynthesis. BMC Evol Biol 6: 109.

Benaroudi N, Lee DH, Goldberg AL (2001) Trehalose accumulation during cellular stress protects cells and cellular proteins from damage by oxygen radicals. J Biol Chem 276: 24261-24267.

Cantarel BL, Coutinho PM, Rancurel C, Bernard T, Lombard V, Henrissat B (2009) The Carbohydrate-Active EnZymes database (CAZy): an expert resource for Glycogenomics. Nucleic Acids Res 37: D233-D238.

Chen YS, Lee GC, Shaw JF (2006) Gene cloning, expression, and biochemical characterization of a recombinant trehalose synthase from Picrophilus torridus in Escherichia coli. I Agric Food Chem 54: 7098-7104.

Crove JH, Crove IM (2000) Preservation of mammalian cells, learning of nature tricks. Nat Biotechnol 18: 145-147.

Drożdżyńska A, Szymanowska D, Czaczyk K (2009) Optymalizacja procesu ekstrakcji trehalozy z komórek drożdży i określenie parametrów jej oznaczania techniką HPLC. Żywność: Nauk. Techn. Jakość 5: 30-42 (in Polish)

Elbein AD, Pan YT, Pastuszak I, Carroll D (2003) New insights on trehalose; a multifunctional molecule. Glycobiology 13: 17-27.

Empadinhas N, da Costa MS (2006) Diversity and biosynthesis of compatible solutes in hyper/thermophiles. Int Microbiol 9: 199-206.

Higashiyama T (2002) Novel functions and applications of trehalose. Pure Appl Chem 74: 1263-1269.

Janecek S (1997) $\alpha$-Amylase family: molecular biology and evolution. Prog Biophys Molec Biol 71: 67-97.

Kato M (1999) Trehalose production with enzymatic system from Sulfolobus solfataricus, I Mol Catal B: Ensym 6: 223-233.

Koh S, Kim J, Shin HJ, Lee DH, Bae J, Kim D, Lee DS (2003) Mechanistic study of the intramolecular conversion of maltose by Thermus caldophilus GK24 trehalose synthase. Carbohydr Res 338: 1339-1343.

Kur J, Olszewski M, Dlugolecka A, Filipkowski P (2005) Single-stranded DNA-binding proteins (SSBs) sources and applications in molecular biology. Acta Biochim Pol 52: 569-574.

Laemmli UK (1970) Cleavage of structural proteins during the assembly of the head of bacteriophage T4. Nature 227: 680-685.

Lenart U, Haplova J, Magdolen P, Farkas V, Palamarczyk G (1995) Evidence for the involvement of a $66 \mathrm{kDa}$ membrane protein in the synthesis of sterolglucoside in Saccharomyces cerevisiae. Acta Biochim Pol 42: 269-274.

Lewis NF (1971) Studies on a radio-resistant coccus isolated from Bombay duck (Harpodon nehereus). J Gen Microbiol 66: 29-35.

Liang L, Chi Z, Wang X, Zhu K (2006) Properties of trehalose6-phosphate synthase from Saccharomycopsis fibuligera. Ann Microbiol 56: 241-245.

Linden A, Mayans O, Meyer-Klaucke Antranikian WG, Willmans M (2003) Differential regulation of a hyperthermophilic $\alpha$-amylase with a novel $(\mathrm{Ca}, \mathrm{Zn})$-dimetal centre by zinc. J Biol Chem 278: 9875-9884.
Lineweaver H, Burk D (1934) The determination of enzyme dissociation constants. I Amer Chem Soc 56: 658-666.

Lowry OH, Rosebrough NJ, Farr AL, Randall RJ (1951) Protein measurement with the Folin phenol reagent. I Biol Chem 193: 265-275.

Ma Y, Xue L, Sun DW (2006) Characteristic of trehalose synthase from permeabilized Psendomonas putida cells and its application in converting maltose to trehalose. J Food Eng 77: 342-347.

Nishimoto T, Nakada T, Chaen H, Fukuda S, Sugimoto T, Kurimoto M, Tsujisaka Y (1997) Action of thermostable trehalose synthase from Thermus aquaticus on sucrose. Biosci Biotechnol Biochem 61: 898899.

Nishimoto T, Nakano M, Nakada T, Chaen H, Fukuda S, Sugimoto $\mathrm{T}$ (1996a) Purification and properties of a novel enzyme, trehalose synthase from Pimelobacter sp. R48. Biosci Biotechnol Biochem 60: 640644.

Nishmoto T, Nakada T, Chaen H, Fukuda S, Sugimoto T, Kurimoto M (1996b) Action of thermostable trehalose synthase from Thermus aquaticus on sucrose. Biosci Biotechnol Biochem 60: 835-839.

Ohguchi M, Kubota N, Wada T, Yoshinaga K, Uritani M, Yagisawa M, Ohishi M, Yamagishi M, Ohta T, Ishikawa K (1997) Purification and properties of trehalose synthesizing enzyme from Pseudomonas sp. F1. J Ferment Bioeng 84: 358-360.

Pan YT, Koroth-Edavana V, Jourdian WJ, Edmonson R, Carrol JD, Pastuszak I, Elbain AD (2008) Trehalose synthase of Mycobacterium smegmatis: purifiacation, cloning, expression, an properties of the enzymes. Eur J Biochem 271: 4259-4269.

Richards AB, Krakowska S, Dexter LB, Schmid H, Wolterbeek APM, Waalkens-Berendsen DH (2002) Trehalose: a review of properties, history of use and human tolerance, and resultes of multiple safety studies. Food Chem Toxicol 40: 871-898.

Roser B (1991) Trehalose, a new approach to premium dried foods. Trends Food Sci Technol 2: 166-169.

Ryu SI, Park CS, Cha J, Woo EJ, Lee SB (2005) A novel trehalosesynthesizing glycosyltransferase from Pyrococcus horikoshii: molecular cloning and characterization. Biochem Biophys Res Commun 329: 429436.

Schiraldi C, di Lernia I, de Rosa M (2002) Trehalose production: exploiting novel approaches. Trends Biotechnol 20: 420-425.

Schwarz A, Godle C, Minani A, Nidetzky B (2007) Trehalose phosphorylase from Pleurotus ostreatus: characterization and covalent modification, and application for the synthesis of $\alpha, \alpha$-trehalose. J Biotechnol 129: 140-150.

Tae-Kyun K, Jun-Hyuck J, Hong-Yeon C, Heung-Shick L, Young-Wan K (2010) Gene cloning and characterization of trehalose synthase from Corynebacterium glutamicum ATCC13032. Food Sci Biotechnol 19: $565-569$.

Teramoto N, Sachinvala ND, Shibata M (2008) Trehalose and trehalose-based polymers for environmentally benign, biocompatible and bioactive materials. Molecules 13: 1773-1816.

Turkiewicz M (2006) Drobnoustroje psychrofilne i ich biotechnologiczny potencjał. Kosmos — Problemy nauk biologicznych 55/4: 307-320 (in Polish).

Wang JH, Tsai MY, Chen JJ, Lee GC, Shaw JF (2007) Role of the C-terminal domain of Thermus thermophilis trehalose synthase in the thermophilicity, thermostability, and efficient production of trehalose. I Agric Food Chem 55: 3435-3443.

Wei YT, Zhu QX, Luo ZF, Chen FZ, Li GY, Huang K, Huang RB (2004) Cloning, expression and identification of a new trehalose synthase gene from Thermobifida fusca genome. Prog Biochem Biophys 31:1018-1023.

Woo EJ, Ryu SI, Song HN, Jung TY, Yeon SM, Lee HA, Park BC, Park KH, Lee SB (2010) Structural insights on the new mechanism of trehalose synthesis by trehalose synthase TreT from Pyrococcus horikoshii. J Mol Biol 404: 247-259.

Wu T'T, Lin SC, Shaw JF (2011) Integrated process for the purification and immobilization of recombinant trehalose synthase for trehalose production. Process Biochem 46(7):1481-1485

Xiuli W, Hongbiao D, Ming Y, Yu Q (2009) Gene cloning, expression and characterization of a novel trehalose synthase from Arthrobacter aurescens. Appl Microbiol Biotechnol 83: 477-482.

Yue M , Wu XL, Gong WN, Ding HB (2009) Molecular cloning and expression of a novel trehalose synthase gene from Enterobacter hormaechei. Microb Cell Fact 8:10-34.

Zdziebło Z, Synowiecki J (2006) Production of trehalose by intramolecular transglucosylation of maltose catalyzed by a new enzyme from Thermus thermophilus. Food Chem 96: 8-13.

Zhu Y, Zhang J, Wie D, Wang Y, Chen X, Xing L, Li M (2008) Isolation and identyfication of a thermophilic strain producing trehalose synthase from geothermal water in China. Biosci Biotechnol Biochem 72: 2019-2024.

Zhu Y, Wei D, Zhang J, Wang Y, Xu H, Xing L, Li M (2010) Overexpression and characterization of a thermostable trehalose synthase from Meiothermus ruber. Extremophiles 14: 1-8. 
